ARTICLE

https://doi.org/10.1038/s41467-019-09268-w

\title{
Nitric oxide-dependent anaerobic ammonium oxidation
}

Ziye $\mathrm{Hu}^{1,3}$, Hans J.C.T. Wessels ${ }^{2}$, Theo van Alen ${ }^{1}$, Mike S.M. Jetten ${ }^{1} \&$ Boran Kartal ${ }^{1,4}$

Nitric oxide (NO) has important functions in biology and atmospheric chemistry as a toxin, signaling molecule, ozone depleting agent and the precursor of the greenhouse gas nitrous oxide $\left(\mathrm{N}_{2} \mathrm{O}\right)$. Although $\mathrm{NO}$ is a potent oxidant, and was available on Earth earlier than oxygen, it is unclear whether NO can be used by microorganisms for growth. Anaerobic ammonium-oxidizing (anammox) bacteria couple nitrite reduction to ammonium oxidation with $\mathrm{NO}$ and hydrazine as intermediates, and produce $\mathrm{N}_{2}$ and nitrate. Here, we show that the anammox bacterium Kuenenia stuttgartiensis is able to grow in the absence of nitrite by coupling ammonium oxidation to NO reduction, and produce only $\mathrm{N}_{2}$. Under these growth conditions, the transcription of proteins necessary for $\mathrm{NO}$ generation is downregulated. Our work has potential implications in the control of $\mathrm{N}_{2} \mathrm{O}$ and $\mathrm{NO}$ emissions from natural and manmade ecosystems, where anammox bacteria contribute significantly to $\mathrm{N}_{2}$ release to the atmosphere. We hypothesize that microbial NO-dependent ammonium oxidation may have existed on early Earth.

\footnotetext{
${ }^{1}$ Department of Microbiology, IWWR, Radboud University Nijmegen, Heyendaalseweg 135, 6525AJ Nijmegen, The Netherlands. ${ }^{2}$ Translational Metabolic Laboratory, Department of Laboratory Medicine, Radboud University Medical Center, Geert Grooteplein-zuid 10, 6525GA Nijmegen, The Netherlands. ${ }^{3}$ Present address: Sanquin, Plesmanlaan 125, 1066 CX Amsterdam, The Netherlands. ${ }^{4}$ Present address: Microbial Physiology Group, Max Planck Institute for Marine Microbiology, Celsiusstraße 1, 28359 Bremen, Germany. Correspondence and requests for materials should be addressed to B.K. (email: bkartal@mpi-bremen.de)
} 
$\mathrm{N}$ itric oxide (NO) is a highly reactive molecule that plays a key role in atmospheric chemistry as an ozone depleting agent and as the precursor of the greenhouse gas nitrous oxide $\left(\mathrm{N}_{2} \mathrm{O}\right)^{1-3}$. In biology $\mathrm{NO}$ has several distinct functions: it is a very potent toxin, but also a signaling molecule and an intermediate in the microbial nitrogen cycle ${ }^{4}$. To remove toxic $\mathrm{NO}$, microorganisms use a multitude of enzymes, and intricate mechanisms that sense, scavenge, and convert $\mathrm{NO}$ to less reactive compounds such as $\mathrm{N}_{2} \mathrm{O}^{5}$. Due to its high reactivity, $\mathrm{NO}$ exists only at very low concentrations in cells, and is rapidly turned over, which is why in both denitrification and aerobic ammonia oxidation it was the last recognized intermediate $e^{6-8}$.

In microbial processes, $\mathrm{NO}$ is either generated via nitrite reduction catalyzed by $\mathrm{Cu}$-containing $(\mathrm{Cu}-\mathrm{NIR})$ or cytochrome $c d_{1}$-containing $\left(c d_{1}\right.$-NIR) nitrite reductases ${ }^{7,9}$, or alternatively by hydroxylamine oxidation catalyzed by octaheme hydroxylamine oxidoreductases $(\mathrm{HAO})^{6,10}$. Intriguingly, microbial growth with $\mathrm{NO}$ as the terminal electron acceptor have not been shown before. However, before molecular oxygen started to accumulate in the atmosphere, NO was the strongest oxidant available on earth ${ }^{11-14}$, which suggests that microorganisms capable of using external NO as the terminal electron acceptor could have evolved early in the history of life.

Anaerobic ammonium-oxidizing (anammox) bacteria use the oxidative power of $\mathrm{NO}$ to activate ammonium in the absence of oxygen. These microorganisms normally use nitrite as their terminal electron acceptor, producing nitrate and $\mathrm{N}_{2}{ }^{15}$. Their catabolism can be described in three main reactions: First, $\mathrm{NO}_{2}{ }^{-}$ is reduced to $\mathrm{NO}$ (Eq. (1)); then $\mathrm{NO}$ and $\mathrm{NH}_{4}{ }^{+}$are condensed into hydrazine $\left(\mathrm{N}_{2} \mathrm{H}_{4}\right)$ by hydrazine synthase (Eq. (2)), which is followed by the oxidation of $\mathrm{N}_{2} \mathrm{H}_{4}$ to $\mathrm{N}_{2}$ by hydrazine dehydrogenase (Eq. (3)). The four electrons released from hydrazine oxidation are used for nitrite reduction (1 electron) and hydrazine synthesis (3 electrons) completing the anammox catabolic cycle. The electrons that are necessary for cell carbon fixation are suggested to be delivered by the oxidation of nitrite to nitrate (Eq. (4)) based on the observation that the growth of anammox bacteria appears to be always associated with nitrate production $^{15,16}$.

$$
\begin{gathered}
\mathrm{NO}_{2}^{-}+2 \mathrm{H}^{+}+\mathrm{e}^{-} \rightarrow \mathrm{NO}+\mathrm{H}_{2} \mathrm{O}\left(E_{0}^{\prime}=+0.38 \mathrm{~V}\right) \\
\mathrm{NO}+\mathrm{NH}_{4}^{+}+2 \mathrm{H}^{+}+3 \mathrm{e}^{-} \rightarrow \mathrm{N}_{2} \mathrm{H}_{4}+\mathrm{H}_{2} \mathrm{O}\left(E_{0}^{\prime}=+0.06 \mathrm{~V}\right) \\
\mathrm{N}_{2} \mathrm{H}_{4} \rightarrow \mathrm{N}_{2}+4 \mathrm{H}^{+}+4 \mathrm{e}^{-}\left(E_{0}^{\prime}=-0.75 \mathrm{~V}\right) \\
\mathrm{NO}_{2}^{-} \rightarrow \mathrm{NO}_{3}^{-}+2 \mathrm{H}^{+}+2 \mathrm{e}^{-}\left(E_{0}^{\prime}=+0.42 \mathrm{~V}\right)
\end{gathered}
$$

While the enzymes responsible for reactions (2)-(4) are conserved in all known anammox genera ${ }^{17}$, nitrite reduction to $\mathrm{NO}$ is catalyzed by distinct enzymes that are also found in other nitrogen-transforming microorganisms ${ }^{7,9}$. The anammox species Kuenenia stuttgartiensis and Scalindua profunda encode $c d_{1}$ $\mathrm{NIR}^{18-20}$, Jettenia spp. encode Cu-NIR ${ }^{21}$, whereas Brocadia spp. do not encode any known nitrite reductases ${ }^{22}$. Moreover, all anammox bacteria encode an octaheme HAO that catalyzes the oxidation of hydroxylamine to $\mathrm{NO}^{10,17}$. It is evident that different anammox species have different NO-forming pathways, which suggests that nitrite reduction to NO might be a trait that was acquired after the core anammox catabolism was already in place. Indeed, reactions (2) and (3) would be sufficient both to conserve energy and supply necessary electrons for cell carbon fixation $\left(\mathrm{CO}_{2}\right)$ for biomass. In this scenario, three of the four electrons released from hydrazine oxidation would be used for hydrazine synthesis, and the remaining electron could be used for biomass production, without the need for nitrite oxidation to nitrate.

To test this hypothesis, a free-living planktonic K. stuttgartiensis culture continuously supplied with ammonium and NO as the only substrates in a continuous membrane bioreactor is employed. We show that $K$. stuttgartiensis is able to use NO as its terminal electron acceptor, and conserve energy and grow by coupling NO reduction to ammonium oxidation in the absence of nitrite. Under these conditions, nitrate is not produced and the sole end product is $\mathrm{N}_{2}$. Using comparative transcriptomics and proteomics, we demonstrate that when growing on NOdependent ammonium oxidation, $K$. stuttgartiensis down regulates the transcription of proteins responsible for NO generation as well as nitrite oxidation.

\section{Results}

NO-dependent anaerobic ammonium oxidation. All continuous bioreactors were operated with free-living planktonic $K$. stuttgartiensis cell cultures (more than 95\% enriched) for more than 50 days ( $\sim 5$ generations). Continuous bioreactors have an intrinsic reproducibility of the measured growth rate, which can be established by removing biomass at a constant rate, and measuring whether the newly grown cells exhibit the same activity for extended periods of time. Here, biomass was constantly removed with a rate of $120 \mathrm{ml} \mathrm{day}^{-1}$ from each bioreactor, all of which had stable activity and growth rate (Fig. 1). Within the first week after inoculation, NO was introduced to reactors II and III and the NO concentration was increased to $450 \mathrm{mg}-\mathrm{N} \mathrm{l}^{-1}$ (32 mM).

In reactor II, where NO was supplied as an additional substrate next to ammonium and nitrite, NO consumption was accompanied with an increase in ammonium oxidation, in line with an earlier study that used flocculent biomass ${ }^{24}$. Ammonium concentration in the effluent decreased from $100 \mathrm{mg}-\mathrm{Nl}^{-1}$ $(7 \mathrm{mM})$ to $25 \mathrm{mg}-\mathrm{Nl}^{-1}(1.8 \mathrm{mM})$, and stayed at this level for the rest of the reactor operation indicating that the anammox bacteria oxidized $228 \mathrm{mg}^{-\mathrm{N} \mathrm{l}^{-1}}(16.3 \mathrm{mM})$ ammonium coupled to $\mathrm{NO}$ reduction (Fig. 1b). In this reactor, NO consumption was

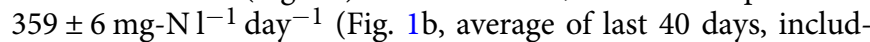
ing standard deviation), corresponding to $\sim 80 \%$ of the NO load.

Reactor III only received ammonium and $\mathrm{NO}$ as substrates. Here, $120 \mathrm{mg}^{-\mathrm{N} \mathrm{day}^{-1}}\left(8.6 \mathrm{mmol} \mathrm{day}{ }^{-1}\right)$ ammonium was oxidized coupled to reduction of $318 \mathrm{mg}-\mathrm{N}^{-1} \mathrm{NO}$ (Fig. 1c, average of last 44 days: $70 \%$ of the NO supplied). This activity was accompanied with a stable growth rate and the ratio of reduced NO to oxidized ammonium was 1.59 , which was close to the predicted stoichiometry of 1.5 (Eq. (5)). Taken together, these results clearly showed that the anammox bacteria were able to conserve energy and grow from anaerobic ammonium oxidation coupled to NO reduction in the absence of nitrite.

$$
6 \mathrm{NO}+4 \mathrm{NH}_{4}^{+} \rightarrow 5 \mathrm{~N}_{2}+6 \mathrm{H}_{2} \mathrm{O}+4 \mathrm{H}^{+}\left(\Delta G_{0}^{\prime}=-1784\right)
$$

Anammox bacteria do not detoxify NO to $\mathrm{N}_{2} \mathrm{O}$. Besides hydrazine synthase, which uses $\mathrm{NO}$ to activate ammonium, anammox bacteria also encode NO-reducing enzymes, such as the flavoprotein norVW (kuste3160 in $K$. stuttgartiensis). Therefore, these microorganisms have the genetic potential to detoxify $\mathrm{NO}$ to $\mathrm{N}_{2} \mathrm{O}$. Still, under all growth conditions, the formed $\mathrm{N}_{2} \mathrm{O}$ was only a minor fraction of the nitrogen load, $\sim 0.025 \%, \sim 0.04 \%, \sim 0.09 \%$ in reactors I, II, and III, respectively. Even though reactors II and III were fed high concentrations of NO, only $0.12 \%$ (Reactor II) and $0.18 \%$ (Reactor III) of removed $\mathrm{NO}$ was converted to $\mathrm{N}_{2} \mathrm{O}$. In line with this observation, transcription levels of norVW (kuste3160) were just above detection 

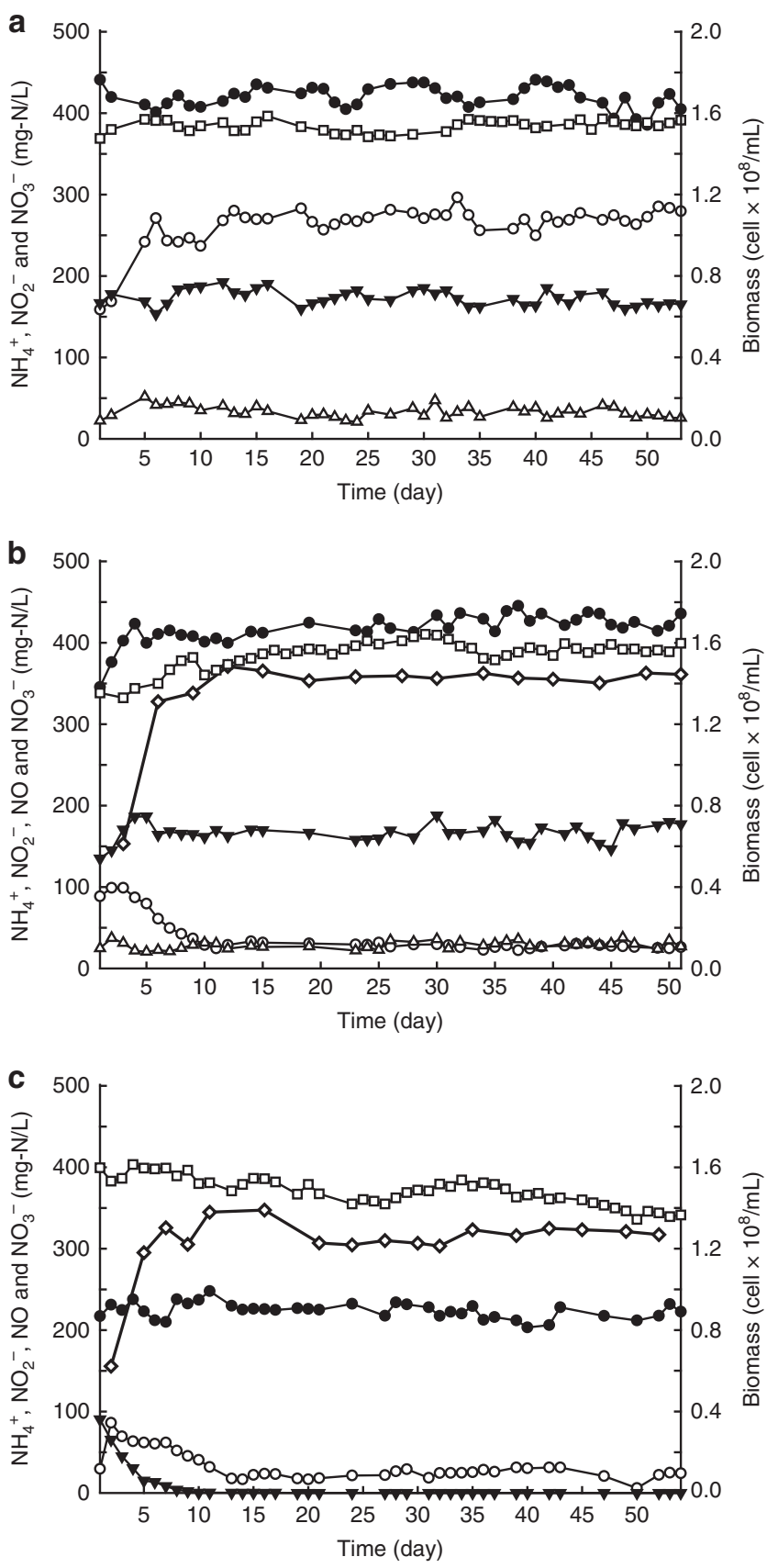

Fig. 1 Nitric oxide, nitrite, ammonium consumption, nitrate production, and biomass growth during reactor operation. (a) reactor I (control reactor, supplied with ammonium and nitrite), (b) reactor II (supplied with ammonium, nitrite, and NO) and (c) reactor III (supplied with ammonium and NO). Filled and empty circles indicate ammonium concentration in the influent and effluent, respectively. Empty triangles indicate nitrite concentration in the influent. Nitrite concentration in the effluent was always below detection limit. Filled triangles indicate nitrate concentration in the effluent. Cell concentration is displayed by cell numbers per $\mathrm{ml}$ (open squares). Nitric oxide (empty diamonds) is displayed as consumption by the bioreactors. This is calcualted from the difference between concentration of nitric oxide in the influent and effluent of the gas phase of the bioreactor. The source data underlying this figure are provided as Source Data file

limit ( 10 reads), and did not change in the reactors that were supplied with NO. The small amount of $\mathrm{N}_{2} \mathrm{O}$ production was likely due to the other community members $(<5 \%)$ present in the $K$. stuttgartiensis cultures, which might be reducing $\mathrm{NO}$ to $\mathrm{N}_{2} \mathrm{O}$ using minute amounts of organic carbon originating from cell decay ${ }^{19}$.

Nitrite oxidation is not needed for growth of anammox bacteria. Anammox growth on ammonium and nitrite is always accompanied by nitrate production, which accounts for up to $20 \%$ of the consumed nitrite ${ }^{16,25}$. Oxidation of nitrite to nitrate is suggested to supply the electrons needed for cell carbon $\left(\mathrm{CO}_{2}\right)$ fixation ${ }^{26}$. Indeed, nitrate production was observed in both reactor I that was supplied ammonium and nitrite, and reactor II, which received ammonium, nitrite, and NO (Fig. 1a, b). The average nitrate concentration in the effluents of reactors I and II (average of last 40 days) were very similar, $29 \mathrm{mg}-\mathrm{Nl}^{-1}$ $(\sim 2.1 \mathrm{mM})$, and $32 \mathrm{mg}^{-\mathrm{Nl}^{-1}}(\sim 2.3 \mathrm{mM})$, respectively.

Conversely, in reactor III, which was supplied with ammonium and NO, nitrate concentration in the effluent decreased to below detection limit $(0.1 \mu \mathrm{M})$ within 1 week after the start of the NO supply, and was not detected for the remainder of the experimental period (Fig. 1c). Apparently under these growth conditions, nitrate was not produced, indicating that anammox bacteria do not acquire the electrons for cell carbon fixation from the oxidation of nitrite to nitrate.

This observation resolves the thermodynamic challenge of reverse electron transport that arises if high potential electrons released from nitrite oxidation to nitrate $\left(E_{0}{ }^{\prime}=+0.43 \mathrm{~V}\right)$ would be used for carbon fixation via the acetyl-CoA pathway, which includes several reactions with very low redox potential (e.g. $E_{0}{ }^{\prime}=-0.42 \mathrm{~V}$ for the reduction of $\mathrm{CO}_{2}$ to formate). On the other hand, coupling the low potential electrons released from hydrazine oxidation to $\mathrm{N}_{2}\left(E_{0}{ }^{\prime}=-0.75 \mathrm{~V}\right)$ to carbon fixation would be very efficient. Indeed, when growing as NO-dependent ammonium oxidizers, this is what the anammox bacteria do.

$$
3 \mathrm{NO}_{2}^{-}+2 \mathrm{H}^{+} \rightarrow 2 \mathrm{NO}+\mathrm{NO}_{3}^{-}+\mathrm{H}_{2} \mathrm{O}
$$

It is highly likely that also when anammox bacteria grow on nitrite and ammonium, the low potential electrons released from hydrazine oxidation to $\mathrm{N}_{2}$ are directed to cell carbon fixation, instead of using electrons from nitrite oxidation to nitrate for this purpose. Consequently, nitrite oxidation to nitrate $\left(E_{0}{ }^{\prime}=+0.43 \mathrm{~V}\right)$ and nitrite reduction to $\mathrm{NO}\left(E_{0}{ }^{\prime}=+0.38 \mathrm{~V}\right)$ are most likely coupled to one another (Eq. (6)). This is thermodynamically more favorable than coupling nitrite oxidation to cell carbon fixation, and indicate that anammox bacteria essentially disproportionate nitrite to nitrate and $\mathrm{NO}$ (Eq. (6)).

Pathways related to nitrite turnover are down-regulated. The use of $\mathrm{NO}$ as the sole electron acceptor was also reflected in the transcriptional activity of the anammox bacteria. When growing on NO and ammonium, 136 genes were up-regulated, and 252 were down regulated over five-fold (Supplementary Data 1 and Supplementary Data 2). As nitrite was not supplied, the most abundant nitrite transporter (kuste3055) was down-regulated 36fold. In line with earlier reports, transcripts of genes encoding the catalytic subunit of the cytochrome $c d_{1}$ nitrite reductase (nirS, kuste4136) and its accessory proteins (kuste4137-kuste4140) were detected in low amounts even under normal nitritedependent ammonium-oxidizing conditions ${ }^{18}$. Nevertheless, under NO-dependent ammonium-oxidizing conditions, all genes in this cluster were strongly down regulated (between 15 and 113 fold): transcription of nirS was 52 fold lower, while the transcription of its proposed redox partner, nirC (kuste4137) decreased from 71 RPKM in the control reactor to below the detection limit (0 reads) (Table 1 ).

Based on the fact that nirS was not abundant in the transcriptome and proteome analyses of $K$. stuttgartiensis, it 
Table 1 Down-regulation of Kuenenia stuttgartiensis genes involved in nitrite and NO metabolisms

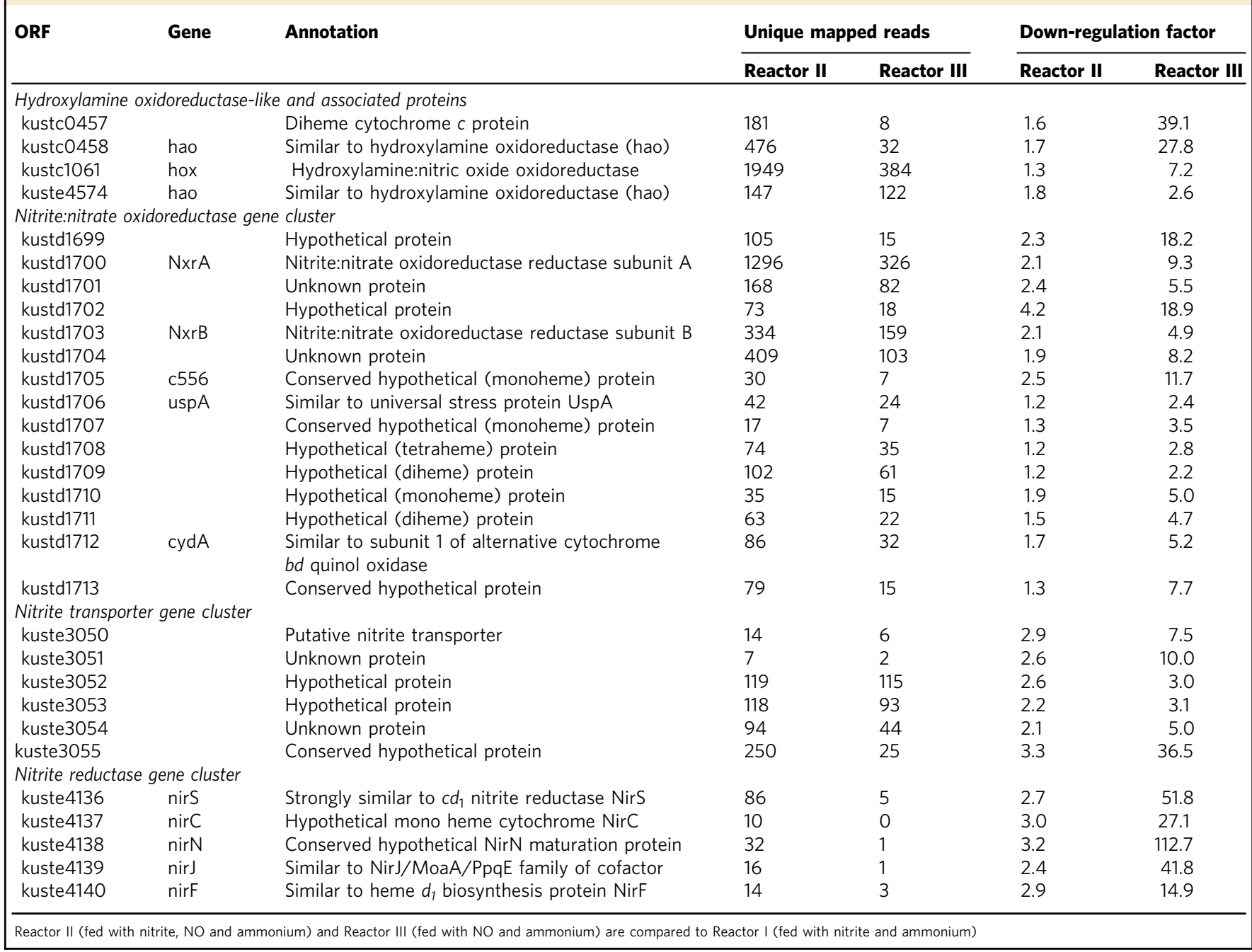

was suggested that other proteins could (also) be responsible for nitrite reduction to NO. Comparative sequence analyses had indicated that octaheme hydroxylamine oxidoreductase (HAO)like proteins encoded by kustc0458 and kuste4574, which have homologs in all known anammox genera, could act as nitrite:NO oxidoreductases $^{15,17}$. The transcriptome analyses showed that octaheme kustc0458 and its diheme redox partner kustc0457 were down-regulated 39 and 28 fold, respectively, in the NO-fed reactor, and were among the 15 most down-regulated proteins. Kuste4574 was also down regulated, albeit only 2.6 fold. Furthermore, kustc1061, which is a dedicated octaheme HAO that oxidizes hydroxylamine to $\mathrm{NO}$, was 7 fold down regulated (Table 1). Taken together, our results suggested that these HAOlike proteins were involved in in vivo $\mathrm{NO}$ production, and kustc0458 could be one of the main enzymes responsible for nitrite reduction to $\mathrm{NO}$ in $K$. stuttgartiensis. In line with the observation that nitrate production did not occur in the NO-fed reactor, the entire gene cluster (kustd1699-kustd1713) that contains nitrite:nitrate oxidoreductase (NXR) and its accessory proteins was down regulated. The genes that encode the soluble, catalytic component, composed of nxrA (kustd1700), nxrB (kustd1703), and nxrC (kustd1704), were down regulated 9.3, 4.9 and 8.2 fold, respectively (Table 1 ).

The down regulation in the transcription of genes involved in nitrite turnover was not reflected at the protein level (Table 2). The vast majority of proteins did not show a dramatic change in abundance between culturing conditions. This discrepancy between transcript and protein levels is a common observation in studies that combine transcriptomics and proteomics since individual protein levels are determined by many different factors that govern the balance between protein synthesis and protein turnover ${ }^{27}$. It is therefore important to integrate rather than correlate both data types to derive novel biological insights ${ }^{28}$. Apparently, anammox bacteria do not rapidly degrade the majority of their proteins. While fast dividing organisms require much higher protein synthesis (and degradation) rates to prevent protein dilution while dividing, the strategy not to rapidly degrade and resynthesize proteins makes sense for slow-growing microorganisms. In this way, they would be able to keep their protein complement primed for conditions that might occur, and thereby reduce their response time to changing substrates.

\section{Discussion}

In the present study, we showed that in the absence of nitrite, anammox bacteria couple ammonium oxidation stoichiometrically to NO reduction, and produce $\mathrm{N}_{2}$ as the sole end product. Taken together with earlier results ${ }^{24}$, our results indicated that this was a common trait in all anammox bacteria. Such a metabolism could have existed on ammoniumrich early earth, where NO was present before the advent of more oxidized nitrogen species such as nitrite and nitrate. Indeed, 


\section{Table 2 Detection of proteins involved in nitrite and NO metabolisms}

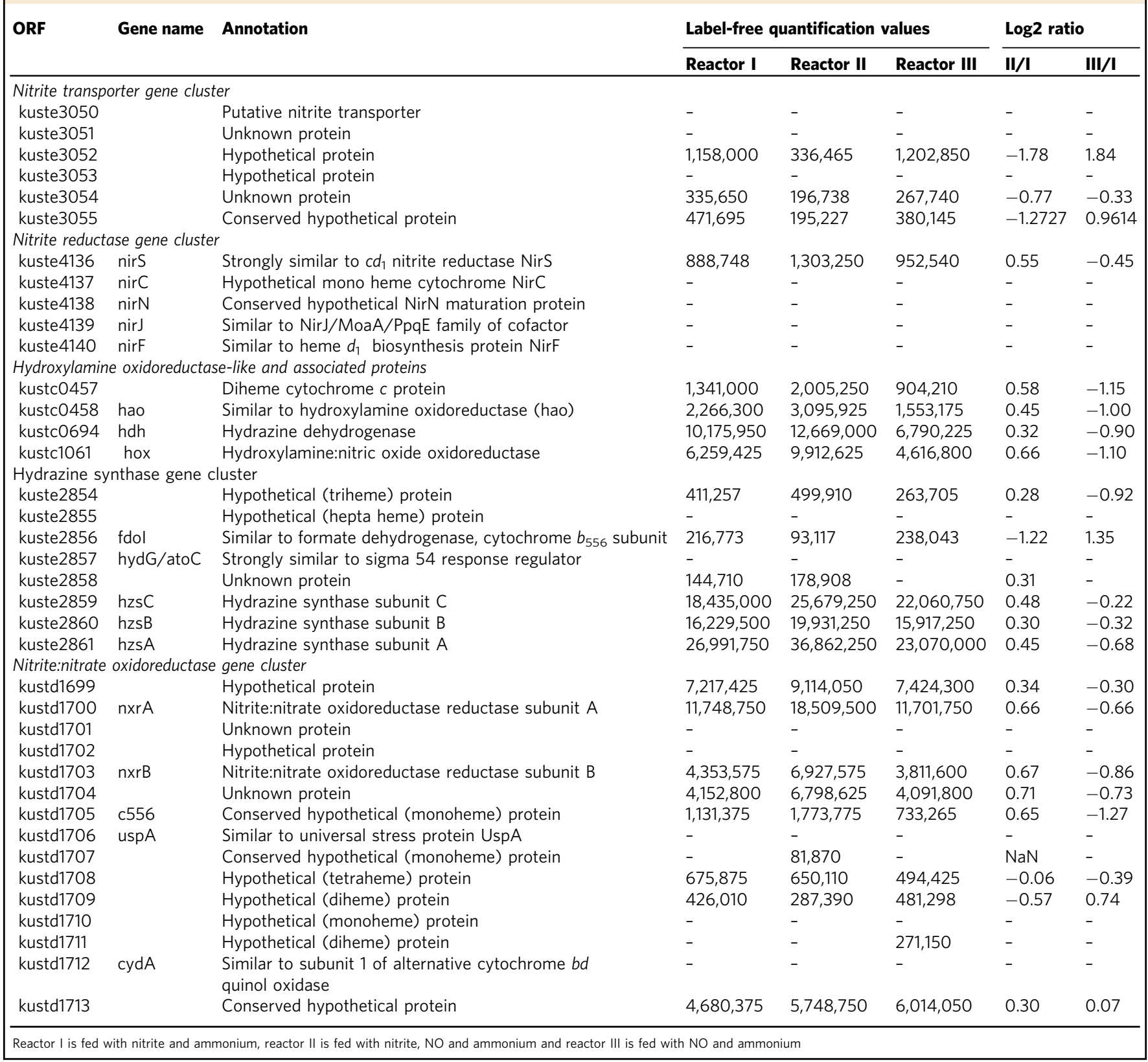

the variability of the nitrite-reducing enzymes in different anammox genera suggests that the ability to reduce nitrite to NO could have been acquired at a later stage. When growing with $\mathrm{NO}$, anammox bacteria did not produce nitrate, refuting the longstanding assumption that nitrate production indicates the growth of anammox bacteria, and that nitrite oxidation to nitrate is required for cell carbon fixation. Instead, anammox bacteria most likely perform nitrite disproportionation by coupling nitrite reduction to $\mathrm{NO}$ with nitrite oxidation to nitrate. Indeed, other forms of disproportionation of nitrite (into $\mathrm{N}_{2}$ and nitrate or $\mathrm{N}_{2} \mathrm{O}$ and nitrate) and $\mathrm{NO}$ (into $\mathrm{N}_{2}$ and nitrate or $\mathrm{N}_{2} \mathrm{O}$ and nitrite or $\mathrm{N}_{2} \mathrm{O}$ and nitrate) might be a widespread trait of nitrogen-transforming microorganisms as both reactions are thermodynamically favorable, and can be carried out by already known enzymes ${ }^{29}$. When anammox bacteria were fed by $\mathrm{NO}$ and ammonium only, all proteins involved in nitrite uptake and consumption were transcriptionally down-regulated.
This observation also singled out the octaheme HAO protein encoded by kustc 0458 as the most likely candidate enzyme that reduces nitrite to NO in $K$. stuttgartiensis. The anammox genus Brocadia lacks both $\mathrm{Cu}-\mathrm{NIR}$ and $c d_{1}$-NIR, but contains kustc0458 homologs, which could be reducing nitrite to NO in Brocadia. The changes in the protein complement of K. stuttgartiensis cells were comparatively less prominent. This highlights the fact that transcriptional regulation is not always reflected by similar changes in protein levels, and that observation of a protein does not necessarily mean that the activity it is implicated in is taking place.

Finally, even though they were supplied large quantities of NO, anammox bacteria did not produce any $\mathrm{N}_{2} \mathrm{O}$, suggesting that in natural and manmade ecosystems these microorganisms consume $\mathrm{NO}$, and convert it to harmless $\mathrm{N}_{2}$ instead of the greenhouse gas $\mathrm{N}_{2} \mathrm{O}$. Consequently, they contribute to controlling the emissions of both $\mathrm{NO}$ and $\mathrm{N}_{2} \mathrm{O}$ two central molecules in atmospheric chemistry. 


\section{Methods}

Reactor setup and operation. Three continuous membrane bioreactors (working volume, $2 \mathrm{l})$ were inoculated with an equal amount $\left(11, \mathrm{OD}_{600}=0.8\right)$ of highly enriched (more than $95 \%$ K. stuttgartiensis cells ${ }^{18}$ ) free-living planktonic cell suspensions of the anammox bacterium $K$. stuttgartiensis, and were operated simultaneously for more than 50 days. The reactors were flushed continuously with $\mathrm{Ar} / \mathrm{CO}_{2}$ $\left(95 \% / 5 \%, 10-15 \mathrm{ml} \mathrm{min}^{-1}\right)$ to maintain anaerobic conditions. The temperature and $\mathrm{pH}$ of the reactors were maintained at $30^{\circ} \mathrm{C}$ and 7.3 with a water bath, and $1 \mathrm{M}$ $\mathrm{KHCO}_{3}$ solution, respectively. The reactors were stirred at $600 \mathrm{rpm}$ with two impellors, one installed just above the gas inlet and the other below the gas-liquid interface of the reactors. Synthetic medium ${ }^{16}$ was supplied at a flow rate of $500-600 \mathrm{ml} \mathrm{day}^{-1}$ to all three reactors. Reactors I and II were supplied with $420 \mathrm{mg}$ $\mathrm{Nl}^{-1}(30 \mathrm{mM})$ ammonium and $168 \mathrm{mg}^{-\mathrm{N}^{-1}}(12 \mathrm{mM})$ nitrite, whereas reactor

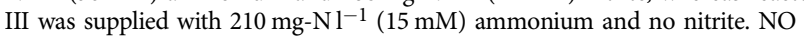
$(10,000 \mathrm{ppm}$, in Argon) was introduced to reactors II and III $36 \mathrm{~h}$ after the startup with a flow rate of $10 \mathrm{ml} \mathrm{min}-1$ and increased to $30 \mathrm{ml} \mathrm{min}^{-1}$ within 2-3 days. NO was bubbled through the reactor in gaseous form. Reactor I was operated as a control reactor and was not supplied with NO. NO consumption was calculated using the difference between the NO concentration in the influent gas phase and the effluent gas phase, taking the flow rate into consideration. The flow rate of $\mathrm{Ar} / \mathrm{CO}_{2}$ in reactor I was increased to $45 \mathrm{ml} \mathrm{min}-1$ to maintain the same total gas flow rate as the other two reactors. To assess growth, optical density at $600 \mathrm{~nm}\left(\mathrm{OD}_{600}\right)$ was monitored during the whole experimental period, which was used to calculate cell numbers per milliliter of reactor volume. After inoculation, when $\mathrm{OD}_{600}$ was stable, for each reactor, biomass was removed constantly from each bioreactor at a rate of $120 \mathrm{ml} \mathrm{day}^{-1}$.

Analytical methods. Liquid samples $(1 \mathrm{ml})$ were collected from the influent and effluent of each reactor every 2-3 days, and were pelleted by centrifugation for $5 \mathrm{~min}$ at $16,000 \times \mathrm{g}$. The supernatants were stored at $-20^{\circ} \mathrm{C}$ until further analyses. Nitrite concentrations were determined colorimetrically at $540 \mathrm{~nm}$ after a $20 \mathrm{~min}$ reaction of $1 \mathrm{ml}$ sample with $1 \mathrm{ml} 1 \%$ sulfanilic acid in $1 \mathrm{M} \mathrm{HCl}$ and $1 \mathrm{ml} 0.1 \% \mathrm{~N}$ naphtylethylenediamine ${ }^{23}$. Ammonium concentrations were determined colorimetrically at $420 \mathrm{~nm}$ after a $30 \mathrm{~min}$ reaction of $40 \mu \mathrm{l}$ sample with $760 \mu \mathrm{l} 0.54 \%$ ortho-phthalaldehyde, $0.05 \% \beta$-mercaptanol, and $10 \%$ ethanol in $400 \mathrm{mM}$ potassium phosphate buffer $(\mathrm{pH} 7.3)^{23}$. The nitrate concentrations were determined by a Sievers Nitric Oxide Analyzer 280i (Analytix Ltd, UK) according to the manufacturer's instructions. The gas inlet and outlet of reactors II and III were connected to an Eco Physics CLD700 EL chemiluminescence $\mathrm{NO}_{\mathrm{x}}$ analyzer (EcoPhysics, Switzerland) every 3-4 days to measure the concentration of $\mathrm{NO} . \mathrm{N}_{2} \mathrm{O}$ was measured at least once a week with an Agilent 6890 Series GC (Agilent Technologies, USA) equipped with a Porapak Q column and an electron capture detector (ECD).

RNA isolation, transcriptome sequencing, and analyses. Biomass ( $8 \mathrm{ml})$ was harvested from all three reactors on day 20 and pelleted by centrifugation for $5 \mathrm{~min}$ at $16,000 \times g$ and stored at $-80^{\circ} \mathrm{C}$ for further use. Total RNA was extracted from the pelleted cells with the RiboPure ${ }^{\mathrm{in}}$ Bacteria kit (Ambion, USA) according to the manufacturer's instructions ${ }^{30}$

Before constructing the transcriptome library, the total RNA concentration and size distribution was determined on an Agilent 2100 Bioanalyzer (Agilent, USA). Messenger RNA (mRNA) was enriched by removing ribosomal RNA from total RNA with the MICROBExpress ${ }^{\mathrm{TM}}$ Bacterial mRNA Enrichment Kit (Ambion, USA). Enriched mRNA was then fragmented and reverse transcription, adapter ligation, and amplification was performed afterwards using Ion Total RNA-Seq Kit (Ion Torrent, USA) according to the manufacturer's instructions. Qualities of the libraries were checked with the Agilent 2100 Bioanalyzer and the Agilent High Sensitivity DNA Kit (Agilent, USA). Libraries were equimolar pooled (20 pM) and fragments were amplified to Ion Sphere particles using the Ion One Touch ${ }^{\mathrm{TM}} 2$ Instrument and Ion PGM ${ }^{\text {sx }}$ Template OT2 200 Kit v2 (Life Technologies, USA) according to the manufacturer's instructions. After enrichment of the TemplatePositive Ion Sphere ${ }^{\mathrm{TM}}$ Particles using the Ion One Touch ${ }^{\mathrm{TM}}$ ES (Life Technologies, USA), they were loaded on an Ion 318 v2 Chip. Subsequently, DNA fragments were sequenced according to the Ion PGM ${ }^{\mathrm{TM}} 200$ Sequencing Kit using 125 cycles (500 flows). Each transcriptome analysis was performed in triplicate. The statistical significance of the triplicate sequencing for each library were examined by $T$-Test in $\mathrm{R}$ program ${ }^{31}$ and showed no significant difference $(p>0.05)$. Thus, reads obtained from each independent sequencing run were combined before they were mapped to the reference genome.

Analyses of transcriptome reads were performed by the CLC Genomics Workbench software (Version 7.0.3, CLC Bio, Denmark). All reads were sizetrimmed and quality-trimmed (maximum number of ambiguities: 2; Quality scores: 0.05) and then mapped to the K. stuttgartiensis genome (accession number PRJNA16685) using RNA-Seq analysis tool with a minimum length of $95 \%$ and a minimum identity of $95 \%$. Before further analyses, transcriptome data of each library were normalized according to the expression value of two RNA polymerase genes rpoB and rpoC (kuste2957, kuste2958) ${ }^{32}$. The changes of gene expression level between NO supplied samples (Reactors II and III) and control sample (Reactor I) were identified by comparing the normalized RPKM (Reads Per Kilobase of exon model per Million mapped reads) value of all CDS to each other (Reactor II vs. Reactor I, Reactor III vs. Reactor I).
Protein and proteome sample preparation and analysis. On day 20 equal amount of biomass $(50 \mathrm{ml})$ were harvested from all three reactors and pelleted by centrifugation for $20 \mathrm{~min}$ at $13,000 \times \mathrm{g}$. Pelleted cells were resuspended in $3 \mathrm{ml}$ $\mathrm{KH}_{2} \mathrm{PO}_{4}(20 \mathrm{mM}, \mathrm{pH} 7)$ solution and $2 \mathrm{ml} \mathrm{KH}_{2} \mathrm{PO}_{4}$, and EDTA-free protease inhibitor cocktail tablet (Roche, Switzerland) was added. Resuspended cells were then lysed with $8 \mathrm{M}$ urea in $10 \mathrm{mM}$ Tris- $\mathrm{HCl}(\mathrm{pH} 8)$ solution for $30 \mathrm{~min}$ at room temperature and sonicated in a bath sonicator for $60 \mathrm{~s}$. Cell remnants were pelleted by centrifugation for $20 \mathrm{~min}$ at $13,000 \times g$ at $4{ }^{\circ} \mathrm{C}$. The supernatants containing protein were transferred to new tubes and stored at $-80^{\circ} \mathrm{C}$ until further analyses Protein concentrations were measured using the Biuret method ${ }^{33}$

Samples were subjected to in-solution tryptic digestion as described elsewhere ${ }^{34}$ Briefly, proteins were reduced in $10 \mathrm{mM}$ DTT for $30 \mathrm{~min}$ at room temperature prior to alkylation by $50 \mathrm{mM}$ chloroacetamide. Proteins were pre-digested using LysC in a 1:50 LysC:protein ratio for $3 \mathrm{~h}$ at room temperature after which the sample was diluted 1:3 with $50 \mathrm{mM}$ ammonium bicarbonate. Trypsin was added in a 1:50 trypsin:protein ratio for overnight digestion at $37^{\circ} \mathrm{C}$. After digestion, all samples were centrifuged to spin down all droplets and $2 \%$ trifluoroacetic acid was added 1:1 to the samples. Subsequent peptide mixtures were desalted and concentrated using C18 Omix tips (Agilent Technologies, USA).

Each sample was analyzed four times by $\mathrm{C} 18$ reversed phase liquid chromatography with online tandem mass spectrometry (LC-MS/MS). Measurements were performed using a nanoflow ultra-high-pressure liquid chromatograph (nano-Advance; Bruker Daltonics, USA) coupled online to an orthogonal quadrupole time-of-flight mass spectrometer (maXis 4G ETD; Bruker Daltonics, USA) via an electrospray ionization source (Captive sprayer; Bruker Daltonics, USA). Five microliters of tryptic digest were loaded onto the trapping column (Acclaim PepMap 100, $75 \mu \mathrm{m} \times 2 \mathrm{~cm}$, nanoViper, $3 \mu \mathrm{m} 100 \AA \mathrm{C} 18$ particles; Thermo Scientific, USA) using $0.1 \%$ formic acid at $7000 \mathrm{nl} \mathrm{min}^{-1}$ for 3 min. Next, peptides were separated on a C18 reversed phase analytical column (Acclaim PepMap RSLC, $75 \mu \mathrm{m} \times 15 \mathrm{~cm}$, nanoViper, $2 \mu \mathrm{m} 100 \AA \mathrm{C} 18$ particles; Thermo Scientific, USA) at $40^{\circ} \mathrm{C}$ using a linear gradient of $5-35 \%$ acetonitrile $0.1 \%$ formic acid in $60 \mathrm{~min}$ at $600 \mathrm{nl} \mathrm{min}-1$. The mass spectrometer was operated in positive ion mode to acquire line spectra in the mass range of $150-2200 \mathrm{~m} / z$. Datadependent acquisition of MS/MS spectra (AutoMSn) was performed using a $3 \mathrm{~s}$ duty cycle at $2 \mathrm{~Hz}$ acquisition rate for full MS spectra and a variable number of MS/ MS experiments at precursor intensity scaled spectra rate $(3 \mathrm{~Hz} \mathrm{MS/MS} \mathrm{spectra} \mathrm{rate}$ @ 2000 counts, $20 \mathrm{~Hz}$ MS/MS spectra rate @ 100,000 counts). Precursor ions within the range of $400-1400 \mathrm{~m} / z$ with chargestate $z \geq 2+$ were selected for MS/MS analysis with active exclusion enabled.

Protein identification and relative quantitation was performed using the MaxQuant software (v.1.6.2.10) ${ }^{35}$ and the Andromeda database search algorithm. Extracted MS/MS spectra were searched against the NCBI RefSeq K. stuttgartiensis proteome database with added sequences of known contaminant proteins. The following settings were used for peptide and protein identification: carbamidomethyl (Cys) as fixed modification, oxidation (Met), and deamidation (NQ) as variable modifications, predefined MS and MS/MS settings for TOF instruments, minimal peptide length of six amino acids and a maximum allowed false discovery rate of $1 \%$ at both the peptide and protein level. Label-free quantitation (LFQ) was performed with the match between runs and re-quantify options using at least 2 razor + unique peptides. Retention time alignment was performed with a time alignment window of $20 \mathrm{~min}$ and a retention time match window of $0.5 \mathrm{~min}$. LFQ values were used for subsequent data analysis. Proteins quantified in at least 3 out of 4 measurements for any growth condition were analyzed for differential expression using the analysis of variance (ANOVA) method with Bonferroni multiple testing correction. Proteins with adjusted $p$-value $<0.05$ were considered to be significantly regulated.

Reporting summary. Further information on experimental design is available in the Nature Research Reporting Summary linked to this article.

\section{Data availability}

The source data underlying Fig. $1 \mathrm{a}-\mathrm{c}$ are provided as Source Data file. The transcriptome sequences from all three reactors have been deposited in the Sequence Read Archive (SRA) under accession number PRJNA485513. Proteomics data have been deposited to the ProteomeXchange Consortium via the PRIDE ${ }^{36}$ partner repository with dataset identifier PXD011763.

Received: 28 November 2018 Accepted: 28 February 2019 Published online: 18 March 2019

\section{References}

1. Bruckdorfer, R. The basics about nitric oxide. Mol. Asp. Med. 26, 3-31 (2005)

2. Hirst, D. G., Robson, T. Nitric Oxide Physiology and Pathology: Nitric Oxide Methods in Molecular Biology (Methods and Protocols) (Humana Press, Clifton, N.J., USA, 2011).

3. Johnston, H. Reduction of stratospheric ozone by nitrogen oxide catalysts from supersonic transport exhaust. Science 173, 517-522 (1971). 
4. Bowman, L. A. H., McLean, S., Poole, R. K. \& Fukuto, J. M. The diversity of microbial responses to nitric oxide and agents of nitrosative stress: close cousins but not identical twins. Adv. Microb. Physiol. 59, 135-219 (2011).

5. Zumft, W. G. The biological role of nitric oxide in bacteria. Arch. Microbiol. 160, 253-264 (1993).

6. Caranto, J. D. \& Lancaster, K. M. Nitric oxide is an obligate bacterial nitrification intermediate produced by hydroxylamine oxidoreductase. Proc. Natl Acad. Sci. USA 114, 8217-8222 (2017).

7. Payne, W. J. Reduction of nitrogenous oxides by microorganisms. Bacteriol. Rev. 37, 409-452 (1973).

8. Zumft, W. G. Cell biology and molecular basis of denitrification. Microbiol. Mol. Biol. Rev. 61, 533-616 (1997).

9. Simon, J. \& Klotz, M. G. Diversity and evolution of bioenergetic systems involved in microbial nitrogen compound transformations. Biochim. Biophys. Acta Bioenerg. 1827, 114-135 (2013).

10. Maalcke, W. J. et al. Structural basis of biological NO generation by octaheme oxidoreductases. J. Biol. Chem. 289, 1228-1242 (2014).

11. Canfield, D. E., Glazer, A. N. \& Falkowski, P. G. The evolution and future of earth's nitrogen cycle. Science 330, 192-196 (2010).

12. Canfield, D. E., Rosing, M. T. \& Bjerrum, C. Early anaerobic metabolisms. Philos. Trans. R. Soc. Lond. B Biol. Sci. 361, 1819-1834 (2006).

13. Kasting, J. F. \& Walker James, C. G. Limits on oxygen concentration in the prebiological atmosphere and the rate of abiotic fixation of nitrogen. J. Geophys. Res. Oceans 86, 1147-1158 (1981).

14. Wong, M. L., Charnay, B. D., Gao, P., Yung, Y. L. \& Russell, M. J. Nitrogen oxides in early earth's atmosphere as electron acceptors for life's emergence. Astrobiology 17, 975-983 (2017).

15. Kartal, B. et al. How to make a living from anaerobic ammonium oxidation. FEMS Microbiol. Rev. 37, 428-461 (2013).

16. Van de Graaf, A. A. V., de Bruijn, P., Robertson, L. A., Jetten, M. S. M. \& Kuenen, J. G. Autotrophic growth of anaerobic ammonium-oxidizing micro-organisms in a fluidized bed reactor. Microbiol.-UK 142, 2187-2196 (1996).

17. Kartal, B. \& Keltjens, J. T. Anammox biochemistry: a tale of heme $\mathrm{c}$ proteins. Trends Biochem. Sci. 41, 998-1011 (2016).

18. Kartal, B. et al. Molecular mechanism of anaerobic ammonium oxidation Nature 479, 127-130 (2011).

19. Strous, M. et al. Deciphering the evolution and metabolism of an anammox bacterium from a community genome. Nature 440, 790-794 (2006).

20. van de Vossenberg, J. et al. The metagenome of the marine anammox bacterium 'Candidatus Scalindua profunda' illustrates the versatility of this globally important nitrogen cycle bacterium. Environ. Microbiol. 15, 1275-1289 (2013).

21. Hu, Z., Speth, D. R., Francoijs, K.-J., Quan, Z.-X., Jetten, M. S. M. Metagenome analysis of a complex community reveals the metabolic blueprint of anammox bacterium "Candidatus Jettenia asiatica". Front. Microbiol. https://doi.org/ $10.3389 /$ fmicb.2012.00366 (2012).

22. Oshiki, M., Shinyako-Hata, K., Satoh, H., Okabe, S. Draft genome sequence of an anaerobic ammonium-oxidizing bacterium, "Candidatus Brocadia sinica". Genome Announc. https://doi.org/10.1128/genomeA.00267-15 (2015).

23. Kartal, B. et al. Adaptation of a freshwater anammox population to high salinity wastewater. J. Biotechnol. 126, 546-553 (2006).

24. Kartal, B. et al. Effect of nitric oxide on anammox bacteria. Appl. Environ. Microbiol. 76, 6304-6306 (2010).

25. Strous, M., Heijnen, J. J., Kuenen, J. G. \& Jetten, M. S. M. The sequencing batch reactor as a powerful tool for the study of slowly growing anaerobic ammonium-oxidizing microorganisms. Appl. Microbiol. Biotechnol. 50, 589-596 (1998).

26. van de Graaf, A. A., deBruijn, P., Robertson, L. A., Jetten, M. S. M. \& Kuenen, J. G. Metabolic pathway of anaerobic ammonium oxidation on the basis of N-15 studies in a fluidized bed reactor. Microbiol.-UK 143, 2415-2421 (1997).

27. Vogel, C. \& Marcotte, E. M. Insights into the regulation of protein abundance from proteomic and transcriptomic analyses. Nat. Rev. Genet. 13, 227-232 (2012).

28. Payne, S. H. The utility of protein and mRNA correlation. Trends Biochem. Sci. 40, 1-3 (2015)
29. Kuypers, M. M. M., Marchant, H. K. \& Kartal, B. The microbial nitrogen cycling network. Nat. Rev. Microbiol. 16, 263-276 (2018).

30. Hu, Z. et al. Nitrogen removal by a nitritation-anammox bioreactor at low temperature. Appl. Environ. Microbiol. 79, 2807-2812 (2013).

31. R Core Team. R: a language and environment for statistical computing. (R Foundation for Statistical Computing, 2013).

32. Wagner, G. P., Kin, K. \& Lynch, V. J. Measurement of mRNA abundance using RNA-seq data: RPKM measure is inconsistent among samples. Theory Biosci. 131, 281-285 (2012).

33. Layne, E. Spectrophotometric and turbidimetric methods for measuring proteins. Methods Enzymol. 3, 447-454 (1957).

34. Wessels, H., Gloerich, J., van der Biezen, E., Jetten, M. S. M. \& Kartal, B. Liquid chromatography-mass spectrometry-based proteomics of Nitrosomonas. Methods Enzymol. 486, 465-482 (2011).

35. Cox, J. \& Mann, M. MaxQuant enables high peptide identification rates, individualized p.p.b.-range mass accuracies and proteome-wide protein quantification. Nat. Biotechnol. 26, 1367-1372 (2008).

36. Vizcaino, J. A. et al. 2016 update of the PRIDE database and its related tools. Nucleic Acids Res. 44, D447-D456 (2016).

\section{Acknowledgements}

The authors thank Marcel Kuypers, Jan Keltjens, and Katharina Ettwig for critical reading of the manuscript. Z.H. and M.S.M.J. were supported by a European Research Council advanced grant (232937). M.S.M.J. was supported by a European Research Council advanced grant (339880). B.K. was supported by a European Research Council starting grant (640422).

\section{Author contributions}

B.K. and Z.H. designed and analyzed experiments. Z.H. maintained cultures, performed activity experiments, analytical measurements and prepared material for transcriptomics and proteomics. Z.H. and T.v.A. performed metatranscriptomics analyses, H.J.C.T.W. performed metaproteomics analyses. Z.H., H.J.C.T.W., M.S.M.J., T.v.A. and B.K. discussed results. B.K. wrote the paper with input from all coauthors.

\section{Additional information}

Supplementary Information accompanies this paper at https://doi.org/10.1038/s41467019-09268-w.

Competing interests: The authors declare no competing interests.

Reprints and permission information is available online at http://npg.nature.com/ reprintsandpermissions/

Journal peer review information: Nature Communications thanks the anonymous reviewer(s) for their contribution to the peer review of this work. Peer reviewer reports are available.

Publisher's note: Springer Nature remains neutral with regard to jurisdictional claims in published maps and institutional affiliations.

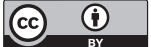

Open Access This article is licensed under a Creative Commons Attribution 4.0 International License, which permits use, sharing, adaptation, distribution and reproduction in any medium or format, as long as you give appropriate credit to the original author(s) and the source, provide a link to the Creative Commons license, and indicate if changes were made. The images or other third party material in this article are included in the article's Creative Commons license, unless indicated otherwise in a credit line to the material. If material is not included in the article's Creative Commons license and your intended use is not permitted by statutory regulation or exceeds the permitted use, you will need to obtain permission directly from the copyright holder. To view a copy of this license, visit http://creativecommons.org/ licenses/by/4.0/.

(C) The Author(s) 2019 